\title{
Ciri-Ciri Kepimpinan Pelajar Pintar dan Berbakat: Implikasi Ke atas Kepimpinan Remaja Islam
}

\author{
Leadership Characteristic of the Gifted and Talented Student: \\ Implication on Islamic Youth Leadership
}

\author{
RORLINDA YUSOF1
}

\begin{abstract}
Leadership is an important characteristic that enables Gifted and Talented Students (GTS) to assume responsibility in the near future. This study aims to examine the levels of leadership characteristic and identify the leadership characteristics profiles amongst GTS. A total of 171 students (93 from High School Gifted Students and 78 from the Pre-University Gifted Students) were involved in the study. The study employs a cross-sectional survey design and data was collected using questionnaire namely Student Leadership Characteristics Questionnaire (SLCQ). Data shows that GTS posses a high level of leadership characteristic. It is also found that collegiality indicates the highest score of the leadership characteristic, followed by leadership behaviour, influence competency, spiritual ethics, work relation, transformation and cohesion. Whereas, self-esteem, leadership efficacy, and visionary were among the average high and selfmonitoring was the lowest leadership characteristic. The findings also indicated that female students possess higher leadership characteristics in comparison to the male students. Races such as Punjab and Bumiputra Sabah and Sarawak descend possess higher scores compared to the Chinese and Malays, whereas the Indians scored the lowest. Lastly, students from the High School Gifted Education Program possess higher leadership characteristics in comparison to the students from PreUniversity Gifted Program. The study has proven that leadership characteristics were embedded in the GTS personality. The findings of this research provided a fundamental basis to be used in the future leadership education program for the gifted students and the leadership character development programs for Islamic youth in local school context.
\end{abstract}

Keywords: gifted and talented students, leadership characteristic, youth leadership

Pembangunan tamadun sesuatu bangsa terletak pada kualiti generasi yang menerajui kepimpinan sesebuah negara. Usaha membina kualiti kepemimpinan generasi muda khususnya para remaja adalah penting. Mereka merupakan aset yang bakal mengisi keperluan kepimpinan negara bagi tujuan kelangsungan pembangunan di masa hadapan. Perhatian masyarakat terhadap pembinaan kualiti kepimpinan remaja khususnya pelajar pintar dan berbakat (PPB) semakin meningkat (Bisland 2004). Keadaan ini berikutan kesedaran masyarakat terhadap keperluan mempunyai pemimpin yang bersedia untuk mengambil tanggungjawab memimpin negara.

PPB didapati mempunyai kebolehan menjadi pemimpin yang hebat kerana mereka dikatakan berkebolehan untuk mendorong dan memotivasikan pelajar-pelajar lain yang berada

\footnotetext{
${ }^{1}$ Rorlinda Yusof, Ph.D., Lecturer, Pusat PERMATApintar Negara, Universiti Kebangsaan Malaysia, 43600 BANGI, Selangor, Malaysia, email: rorlinda@ukm.edu.my.
} 
di sekeliling mereka (Karne \& Stephens 1999). Justeru, Robert (2013) mencadangkan bahawa kepimpinan adalah satu kemestian bagi PPB. Beliau selanjutnya menegaskan bahawa sepertimana pelajar yang mempunyai bakat dalam bidang seni visual dan sukan, pelajar yang menunjukkan bakat kepimpinan juga perlu dibina kemahiran kepemimpinannya. Potensi kepimpinan ini perlu dikenalpasti, malah bakat mereka perlu diasah dan diberi peluang untuk dikembangkan dalam pelbagai sudut. Untuk itu, The National Association for Gifted Children (2010) menyarankan agar institusi yang terlibat dengan PPB perlu membentuk persekitaran iaitu pelajar-pelajar ini boleh memupuk ciri kepimpinan menerusi penglibatan dalam pelbagai aktiviti komuniti atau kemasyarakatan. Apa yang lebih penting ialah PPB perlu diberi peluang untuk mengenalpasti dan menyedari potensi diri bagi membolehkan mereka menyumbang kepada masyarakat. Sekiranya bakat kepimpinan ini tidak dicungkil dan dipupuk dengan baik, individu yang mungkin dilahirkan pintar, tidak akan berkembang untuk menjadikan dia seorang yang berbakat sepenuhnya (Gagne 2009).

PPB dikenali sebagai individu yang mempunyai daya intelektual yang tinggi dan mempunyai kecekapan dalam menyelesaikan masalah. Gagne (2009) mendefinisikan pelajar pintar sebagai individu yang mempunyai kebolehan atau potensi semula jadi dan kebolehan ini boleh dikembangkan menjadi bakat menerusi persekitaran dan faktor-faktor lain. Kebolehan semula jadi individu berbakat ini merangkumi kebolehan mental yang mencakupi aspek intelektual, kreativiti, sosioafektif dan perseptual, serta kebolehan fizikal yang mencakupi aspek sensorimotor. Kepimpinan merupakan salah satu kebolehan semula jadi yang terkandung dalam domain sosioafektif. Individu yang memiliki kebolehan kepimpinan didapati berbakat dalam aspek komunikasi yang melibatkan keupayaan untuk berempati, kreatif dalam menggunakan daya pujuk untuk mempengaruhi orang lain. Kebolehan dan bakat tersebut selari dengan definisi kepemimpinan oleh Terry (2006) yang menyatakan kepemimpinan adalah kegiatan-kegiatan untuk mempengaruhi orang lain agar mahu bekerjasama untuk mencapai tujuan kelompok secara sukarela. Potensi semula jadi yang dimiliki ini meneguhkan pandangan Renzulli (1978) tentang tingklah laku pelajar pintar dan berbakat di mana mereka biasanya berupaya menerapkan tiga kelompok asas tret kemanusiaan semula jadi mereka iaitu menunjukkan kebolehan spesifik yang melebihi tahap purata, mempunyai komitmen tugas yang sangat tinggi dan menghayati daya kreativiti dalam bidang-bidang yang dicenderungi.

Selain itu, pelajar yang mempunyai potensi kepimpinan ini juga dilihat sebagai golongan yang bersedia untuk berkongsi ciri-ciri kepimpinan yang umum seperti kemahiran mengendalikan kumpulan, mendorong dan memotivasi orang lain, menyelesaikan masalah secara kreatif, menggunakan kemahiran komunikasi yang berkesan, melihat peluang dalam sesebuah perhubungan, luwes dalam pemikiran dan tindakan, mudah memahami konsepkonsep yang kabur, cekap menstruktur matlamat dan objektif serta dapat menilai proses kumpulan untuk mencapai sesuatu matlamat (Bisland 2004; Feldhusen \& Bleiss 1994; Karnes \& Bean 1996). Kajian lepas turut mengaitkan ciri kepemimpinan PPB dengan kecekapan mengurus emosi, kemampuan menggunakan kepintaran, kreatif dan membuat pertimbangan kritikal dalam menyelesaikan masalah (Chan 2003; Karnes \& Bean 1996). Ringkasnya, hampir kesemua ciri peribadi PPB yang tersenarai merupakan kualiti utama yang menjadi asas dalam pembinaan peribadi seorang pemimpin.

\section{Pernyataan Masalah}

Kualiti kepemimpinan PPB sering dikaitkan dengan sifat-sifat peribadi pelajar itu sendiri. Antara ciri peribadi yang menjadi pemangkin dalam menjana kualiti kepemimpinan PPB menurut Karnes dan Bean (1996) termasuklah keinginan yang suka dicabar, daya tahan menyelesaikan masalah, kebolehan membuat pertimbangan yang kritikal, kesediaan membina perhubungan baharu dan keberanian mengekspresi pandangan secara verbal. Meskipun telah diakui bahawa menjana kepintaran kepimpinan dalam diri PPB adalah penting, namun 
Sternberg (2004) mendapati kajian berkaitan PPB sering mengabaikan aspek ini. Penyataan tersebut menyokong pandangan Chan (2003) yang menyatakan usaha mendokumentasi dan menilai keberkesanan program latihan kepimpinan PPB menjadi suatu keperluan yang mendesak bagi mempastikan supaya bakal pemimpin yang berpotensi dalam kalangan pelajar ini boleh dilatih secara berkesan untuk menyedari bakat kepemimpinannya.

Sehubungan itu, Philips (2009) menegaskan bahawa adalah penting bagi para pendidik, ibu bapa dan pihak-pihak yang mengambil berat serta berminat dalam membina kepimpinan PPB untuk menyedari hakikat ini kerana mereka boleh membuat perubahan dalam kehidupan pelajar berkenaan. Untuk itu pelajar PPB perlu terlebih dahulu dibimbing untuk mengenalpasti bakat atau potensi kepemimpinan dalam diri masing-masing. Pandangan tersebut diperkukuh dengan pengalaman Landau dan Weissler (1991) yang mendapati PPB yang mempunyai bakat kepimpinan ini biasanya tidak melihat diri mereka sebagai pemimpin atau tidak yakin dan mengharapkan kedudukan tersebut. Menurut kajiannya lagi, kegagalan dalam mengesan potensi kepimpinan dalam diri pelajar ini akan melambatkan proses membangunkan kebolehan luar biasa PPB. Sebaliknya, keupayaan mengesan potensi ini boleh menyedarkan PPB akan tanggungjawab dan kepentingan peranan mereka dalam membangunkan masyarakat dan negara.

Hasil kajian kepimpinan dalam kalangan PPB didapati tertumpu kepada elemen personaliti yang melibatkan ciri-ciri tenaga dan dorongan pemimpin yang boleh menyumbang kepada kepentingan kumpulan yang dipimpin (Staw \& Basade 1993). Individu yang memiliki ciri-ciri personaliti yang dikategorikan sebagai positif afektif (iaitu memiliki ciri kawalan perasaan yang positif, memiliki tenaga dan kuasa dorongan yang tinggi) dikatakan bersikap kompeten dalam perhubungan interpersonal dan akan menyumbang lebih kepada aktiviti kumpulan. Keupayaan mempamerkan kuasa personaliti kepimpinan yang bertenaga boleh menjadikan individu berjaya menanamkan keseronokan dan menjana tenaga ke dalam aktiviti kumpulan (Staw \& Basade 1993). Sejajar dengan itu, ciri pintar kepemimpinan juga dikaitkan dengan tiga belas kualiti; berkebolehan merangsang dan membangkitkan semangat orang lain dalam sesuatu perkara, mengenalpasti kemahiran dan kebolehan yang dimiliki oleh orang lain, mudah berinteraksi dengan orang lain, menunjukkan kemahiran sosial yang tinggi, berkebolehan mengenalpasti matlamat sesuatu perkara dan menyatakannya dengan jelas, berkebolehan menerangkan idea dengan jelas kepada pendengar, sangat empati terhadap perasaan orang lain, berkebolehan memberi arahan dengan jelas dan berkesan, mengamalkan kepimpinan yang telus dan bertanggungjawab serta boleh mengkordinasi tugasan daripada beberapa orang individu, berkebolehan menjana perasaan positif sesuatu kumpulan dan sangat memahami perasaan orang lain, orang yang boleh membuat keputusan serta menyokong ahli kumpulan bila perlu sahaja, selalu diminta untuk memberi pandangan dan cadangan, berani melakukan yang baru, dan ada kecenderungan untuk mengawal rakan sebaya dalam sesuatu situasi (Aliza \& Hamidah 2009; Rosadah et al. 2009). Ringkasnya, individu yang memiliki sifatsifat dan ciri-ciri afektif positif lebih cenderung untuk melibatkan diri dalam tingkah laku yang dikaitkan dengan kepimpinan berkesan. Justeru, menyedarkan PPB tentang kelebihan pada ciriciri tersebut bukan sahaja dapat membina keyakinan diri, malah dapat menjadi pemangkin dalam menjana perkembangan potensi kepimpinan diri mereka.

Sehubungan itu, Duke (2011) dan Sisk (2000) menjelaskan ciri kepemimpinan boleh ditingkat dan diperbaiki. Bermula daripada kesedaran tentang ciri kepimpinan yang dimiliki, disusuli dengan pendedahan kepada peluang membina kepimpinan menerusi pelbagai aktiviti. Cara tersebut dikatakan boleh membina kemahiran dan memacu kecekapan memimpin pelajar PPB. Saranan ini sejajar dengan pandangan Karnes \& Bean (1996) yang menyatakan proses membina kualiti kepimpinan perlu dilalui secara berterusan menerusi pelbagai pendedahan dan pengalaman kokurikulum pada setiap peringkat perkembangan. Seterusnya Duke (2011) menegaskan, usaha ini bukan terletak pada jawatan dan kedudukan sebagai ketua atau 
pemimpin, sebaliknya proses pengalaman melibatkan diri dalam merangka dan melaksanakan perancangan adalah kunci utama yang dapat mengembangkan potensi kepemimpinan pelajar.

Sehubungan itu, kajian ini akan mengenalpasti ciri-ciri kepimpinan dalam kalangan PPB di Pusat PERMATApintar Negara, Universiti Kebangsaan Malaysia (UKM). Empat belas ciri kepimpinan dikaji; efikasi kepemimpinan, kemahiran hubungan kerja, motivasi untuk memimpin, kecekapan mempengaruhi, tingkah laku kepimpinan, kepercayaan, pemuafakatan, kesepaduan/ kejelekitan, penghargaan kendiri, penghayatan nilai kerohanian, kepintaran emosi, pemantauan kendiri, wawasan dan sifat transformasi. Kajian ini bertujuan untuk mengesan potensi kepemimpinan dalam diri PPB di Pusat PERMATApintar Negara. Dapatan ini merupakan langkah pertama dalam usaha mengenalpasti bakat kepemimpinan PPB ke arah melahirkan pemimpin masa depan yang berkesan dan cemerlang. Kajian ini turut melihat perbezaan ciri-ciri kepimpinan berdasarkan faktor demografi seperti jantina, kaum dan jenis program yang diikuti.

\section{Objektif Kajian}

Kajian ini bertujuan untuk mengesan ciri-ciri atau potensi bakat kepimpinan dalam diri PPB. Satu profil kepemimpinan PPB akan dibina untuk mengenalpasti ciri-ciri dan tahap kepimpinan dalam kalangan PPB. Objektif kajian ini akan dijawab menerusi persoalan kajian. Pertama, apakah profil kepimpinan pelajar pintar dan berbakat di Pusat PERMATApintar Negara UKM secara keseluruhan? Kedua, apakah profil kepimpinan pelajar pintar dan berbakat mengikut jantina, kaum dan program di Pusat PERMATApintar Negara UKM?

\section{Kajian Literatur Konstruk Kepimpinan}

\begin{tabular}{|c|c|}
\hline Konstruk & Huraian \\
\hline Efikasi Kepimpinan & $\begin{array}{l}\text { Ciri ini mempamerkan keupayaan untuk berjaya mempengaruhi sesuatu } \\
\text { keputusan/ hasil kerja seseorang. Individu ini mempunyai kepercayaan dalaman } \\
\text { yang kuat bahawa dia boleh mencapai kejayaan dalam tugas yang dijalankan. } \\
\text { Kepercayaan dalaman ini dikaitkan dengan tahap keyakinan yang tinggi dari aspek } \\
\text { pengetahuan, kemahiran dan kebolehan untuk memimpin (Sherer et al. 1992). }\end{array}$ \\
\hline Hubungan Kerja & $\begin{array}{l}\text { Sifat ini menunjukkan individu mempunyai keupayaan untuk membina hubungan } \\
\text { kerja yang baik dengan individu lain dalam mencapai matlamat yang sama. } \\
\text { Hubungan kerja yang baik ini diterjemahkan menerusi penyertaan aktif dan } \\
\text { komitmen dalam menyiapkan tugasan secara bersama dengan individu lain } \\
\text { (Meyer \& Alen 1997). }\end{array}$ \\
\hline $\begin{array}{l}\text { Motivasi } \\
\text { Kepimpinan }\end{array}$ & $\begin{array}{l}\text { Individu yang mempunyai sifat cenderung untuk mencapai, bercita-cita tinggi, } \\
\text { bertenaga, tekun, berdaya usaha, menghayati sifat-sifat yang bermotifkan kuasa } \\
\text { sosialisasi dan pengaruh untuk mencapai visi atau matlamat yang diharapkan. } \\
\text { Mereka juga menunjukkan keupayaan untuk membangunkan jaringan dan pakatan } \\
\text { untuk mendapatkan kerjasama orang lain, menyelesaikan konflik dengan cara } \\
\text { yang membina dan untuk mempengaruhi orang lain menerusi contoh dan teladan } \\
\text { (Chan \& Drasgow 2001). }\end{array}$ \\
\hline $\begin{array}{l}\text { Kecekapan } \\
\text { Mempengaruhi }\end{array}$ & $\begin{array}{l}\text { Individu ini mempengaruhi orang lain dengan menggunakan pemikiran yang } \\
\text { rasional untuk membangunkan prestasi dan kepuasan dalam kalangan pengikut. } \\
\text { Matlamat ini dicapai melalui kemahiran meyakinkan, pertukaran idea, } \\
\text { menunjukkan kemahiran memihak kepada orang lain, penyatuan pendapat, } \\
\text { memberi inspirasi dan perundingan (Yukl \& Falbe 1990). }\end{array}$ \\
\hline $\begin{array}{l}\text { Tingkah laku } \\
\text { Kepimpinan }\end{array}$ & $\begin{array}{l}\text { Individu ini terlibat dalam tiga jenis tingkah laku kepimpinan yang berbeza; (1) } \\
\text { kepimpinan sokongan iaitu terlibat dalam membuat orang lain merasa dihargai, } \\
\text { (2) kepimpinan yang menekankan kepada kepentingan matlamat iaitu terlibat }\end{array}$ \\
\hline
\end{tabular}




\begin{tabular}{|c|c|}
\hline & $\begin{array}{l}\text { dalam merangsang tekad untuk mencapai matlamat kumpulan atau prestasi yang } \\
\text { sangat baik, (3) penyeliaan iaitu melibatkan diri dalam tingkah laku memudahkan } \\
\text { pencapaian matlamat melalui aktiviti-aktiviti seperti penjadualan, menyelaras, } \\
\text { merancang dan peruntukan sumber seperti alat-alat, bahan dan pengetahuan } \\
\text { teknikal (Burke et al. 2006). }\end{array}$ \\
\hline Kebolehpercayaan & $\begin{array}{l}\text { Individu-individu ini boleh dipercayai kerana mencerminkan kebolehpercayaan, } \\
\text { integriti, kejujuran, keadilan dan amat mengambil berat kebajikan orang lain } \\
\text { (McAllister 1995). }\end{array}$ \\
\hline Pemuafakatan & $\begin{array}{l}\text { Individu-individu ini mempunyai rasa kekitaan dalam kerja berpasukan. Mereka } \\
\text { memberi sokongan dan kerjasama dalam mewujudkan perdamaian dan harmoni } \\
\text { dalam pasukan (Matsumoto et al. 1997). }\end{array}$ \\
\hline $\begin{array}{l}\text { Kesepaduan/ } \\
\text { Kejelekitan }\end{array}$ & $\begin{array}{l}\text { Individu-individu ini menunjukkan keupayaan untuk bekerja rapat dengan orang } \\
\text { lain. Terdapat kesepaduan dalam hubungan kerja yang mewujudkan persekitaran } \\
\text { yang selesa bekerja (Pearce 2004). }\end{array}$ \\
\hline $\begin{array}{l}\text { Penghargaan } \\
\text { Kendiri }\end{array}$ & $\begin{array}{l}\text { Individu ini mempunyai harga diri yang tinggi dan sentiasa positif tentang } \\
\text { persekitaran kerja mereka (Pierce et al. 1998). }\end{array}$ \\
\hline $\begin{array}{l}\text { Etika Nilai } \\
\text { Kerohanian }\end{array}$ & $\begin{array}{l}\text { Individu ini menghargai nilai kerohanian yang tinggi sepanjang masa dalam } \\
\text { kehidupan. Fokus utama individu ini adalah untuk mencapai keharmonian sejagat } \\
\text { melalui nilai etika dan integriti, kebebasan dan keadilan (Heerman 1995). Ciri ini } \\
\text { diterjemahkan melalui kejujuran dalam memahami matlamat, falsafah dan visi } \\
\text { organisasi mahu dicapai. Mereka komited untuk membuat sumbangan, } \\
\text { berinteraksi dengan mudah dan mengamalkan kepercayaan bersama. Mereka juga } \\
\text { berfikiran terbuka, kreatif, komited untuk kerjasama dan perkongsian serta jujur } \\
\text { dalam semua hubungan interpersonal (Brown \& Harrison 2005; Heerman 1995). }\end{array}$ \\
\hline Kecerdasan Emosi & $\begin{array}{l}\text { Individu mempunyai keupayaan untuk mengenalpasti emosi, mengakses dan } \\
\text { menjana emosi untuk membantu berfikir, memahami emosi untuk membolehkan } \\
\text { dia mengawal emosi serta menggalakkan perkembangan pengetahuan emosi dan } \\
\text { perkembangan intelek (Tapia 2001). }\end{array}$ \\
\hline $\begin{array}{l}\text { Pemantauan } \\
\text { Kendiri }\end{array}$ & $\begin{array}{l}\text { Mempunyai keupayaan untuk membaca dan memotivasi diri dalam menyahut } \\
\text { isyarat sosial bagi menyesuaikan diri dengan individu-individu dalam } \\
\text { persekitaran. Individu ini lebih cenderung untuk melibatkan diri dalam tingkah } \\
\text { laku yang dilihat oleh orang lain sebagai menarik dan tingkah laku yang } \\
\text { diperlukan untuk menjadi pemimpin. Matlamat ini menjadikan mereka lebih } \\
\text { cenderung untuk muncul sebagai pemimpin berbanding rakan-rakan lain yang } \\
\text { mempunyai pemantauan kendiri yang rendah (Dobbins etal. 1999). }\end{array}$ \\
\hline Wawasan & $\begin{array}{l}\text { Pemimpin berwawasan sentiasa cuba untuk bergerak ke arah orang lain dalam } \\
\text { satu wawasan bersama. Mereka menyatakan dengan jelas hala tuju yang dicapai, } \\
\text { namun mereka tidak menentukan bagaimana untuk mencapainya. Ahli yang } \\
\text { bermotivasi akan berusaha untuk mencapai hala tuju yang ditetapkan. Individu ini } \\
\text { juga akan secara terbuka berkongsi maklumat, yang membawa kepada sikap } \\
\text { perkongsian pengetahuan dengan ahli-ahli mereka, juga orang lain. Secara amnya, } \\
\text { gaya ini mempunyai kesan yang kuat ke atas persekitaran khususnya persekitaran } \\
\text { kerja (Goleman et al. 2010). }\end{array}$ \\
\hline Transformasi & $\begin{array}{l}\text { Individu ini mementingkan penghasilan seperti kepuasan, komitmen dan prestasi } \\
\text { cemerlang (Pillai \& William 2004). Sentiasa berusaha untuk mempengaruhi } \\
\text { tingkah laku ahli-ahlinya melalui ciri-ciri tingkah laku dan peribadi. Mereka } \\
\text { menghormati, yakin dan suka memotivasikan ahli-ahli mereka untuk } \\
\text { meningkatkan keberkesanan kumpulan atau organisasi. Mereka mampu } \\
\text { mengubah sikap, motivasi, meningkatkan komitmen dan moral ahli kumpulan } \\
\text { dengan menggalakkan mereka untuk meletakkan matlamat kumpulan mendahului } \\
\text { kepentingan peribadi (Mansfield 2014). Mereka sentiasa berusaha untuk } \\
\text { memahami dan menghargai ahli-ahli selain mencari pendekatan baru untuk } \\
\text { mengatasi masalah dan menghadapi cabaran. Sikap prihatin dan kemanusiaan } \\
\text { yang tinggi membolehkan mereka berjaya mendapat kepercayaan dan kesetiaan } \\
\text { ahli-ahli. }\end{array}$ \\
\hline
\end{tabular}




\section{Metode Kajian}

Kajian deskriptif ini merupakan kajian kuantitatif yang menggunakan kaedah tinjauan untuk melihat ciri-ciri kepimpinan dalam kalangan PPB. Data diperolehi daripada soal selidik kepimpinan yang merupakan instrumen utama kajian. Soal selidik kajian dibina berdasarkan 'Model Proses Kepimpinan' dalam Leadership Process Self-Assessment (Locke et al. 1991). Soal selidik ini diberi skala Likert 5 mata dengan menggunakan kadar dari 'Sangat Tidak Setuju' kepada 'Sangat Setuju'. Dari sudut 'Sampel Kajian', soal selidik diedarkan kepada PPB di Pusat PERMATpintar Negara UKM yang belajar dalam Program Pendidikan Menengah dan Program Pra Universiti ASASIpintar. Seramai 171 orang pelajar telah dipilih secara rawak mudah untuk memberi respon kepada soal selidik kajian. Daripada jumlah tersebut, 93 orang (54.4\%) daripada program pendidikan dan 78 orang (45.6\%) daripada program ASASIpintar. 106 (62\%) adalah pelajar perempuan dan 65 (38\%) pelajar lelaki. Dari segi komposisi kaum, 127 (74.3\%) terdiri daripada pelajar Melayu, 24 (14\%) pelajar Cina, 8 (4.7\%) pelajar India, dan 12 (7.0\%) lain-lain kaum iaitu Sikh dan Borneo. Bagi sudut 'Instrumen Kajian' pula, ia adalah soal selidik yang mengandungi empat belas (14) konstruk yang menggambarkan ciri-ciri kepimpinan yang dikaji. Konstruk-konstruk tersebut ialah efikasi kepimpinan, hubungan kerja, motivasi memimpin, kecekapan mempengaruhi, tingkah laku atau gaya/ tingkah laku kepimpinan, kepercayaan, pemantauan kendiri, kesepaduan, penghargaan kendiri, penghayatan nilai kerohanian, kepintaran emosi, pemantauan kendiri, wawasan kendiri, dan ciri transformasional. Soal selidik ini mengandungi tujuh puluh item (70), setiap konstruk mengandungi lima item. Respon terhadap item adalah berdasarkan skala Likert 5 mata bermula dengan; 1-Sangat Tidak Setuju, 2-Tidak Setuju, 3-Tidak Pasti, 4-Setuju, dan 5-Sangat Setuju. Nilai pekali korelasi kebolehpercayaan instrumen dalam kajian rintis $(n=50)$ adalah $\alpha 0.863$. Berdasarkan nilai kebolehpercayaan yang tinggi ini, instrumen ini sesuai digunakan dan boleh dipercayai untuk memperoleh skor yang stabil daripada responden. Untuk sudut 'Kaedah Pengumpulan Data', ia dijalankan melalui pengedaran Soal Selidik Kepimpinan semasa kursus pengajaran Subjek Kepimpinan dan Penyelesaian Masalah (untuk pelajar Program ASASIpintar) dan kursus Jatidiri (untuk pelajar Program Pendidikan). Responden menjawab soal selidik dalam satu masa yang sama dan tiada had masa yang ditetapkan. Seterusnya, bagi 'Analisis Data', hasil kajian dianalisis dengan menggunakan bantuan perisian SPSS 19.0. Analisis deskriptif dijalankan bagi menentukan profil demografi kajian, profil kepimpinan pelajar pintar dan berbakat secara keseluruhan dan mengikut jantina, bangsa dan kumpulan.

\section{Dapatan Kajian}

Analisis dapatan kajian dihuraikan mengikut persoalan kajian yang telah dinyatakan pada bahagian sebelumnya. Huraian analisis dapatan kajian dipaparkan secara terperinci iaitu pada 'Profil Kepimpinan Pelajar Pintar dan Berbakat di Pusat PERMATA Pintar Negara UKM' dan 'Profil Kepimpinan PPB di Pusat PERMATA pintar Negara UKM Mengikut Jantina, Kaum dan Program'.

\section{Profil Kepimpinan Pelajar Pintar dan Berbakat di Pusat PERMATA Pintar Negara UKM}

Secara keseluruhannya profil kepimpinan PPB di Pusat PERMATA pintar Negara Universiti Kebangsaan Malaysia dirumuskan seperti Jadual 1 di bawah:

\begin{tabular}{llccc}
\hline No. & Kepimpinan & Min & $\begin{array}{c}\text { Sisihan } \\
\text { piawai }\end{array}$ & Interpretasi \\
\hline 1 & Efikasi Kepemimpinan & 3.86 & 0.47 & Tinggi \\
2 & Kemahiran Hubungan Kerja & 4.17 & 0.48 & Tinggi \\
3 & Motivasi untuk Memimpin & 3.93 & 0.62 & Tinggi
\end{tabular}




\begin{tabular}{lllll}
\hline 4 & Kecekapan Mempengaruhi & 4.27 & 0.51 & Tinggi \\
5 & Tingkahlaku Kepimpinan & 4.29 & 0.54 & Tinggi \\
6 & Kepercayaan & 4.00 & 0.57 & Tinggi \\
7 & Pemuafakatan & 4.44 & 0.47 & Tinggi \\
8 & Kesepaduan & 4.05 & 0.52 & Tinggi \\
9 & Penghargaan Kendiri & 3.90 & 0.59 & Tinggi \\
10 & Etika Penghayatan Kerohanian & 4.23 & 0.48 & Tinggi \\
11 & Kepintaran Emosi & 3.98 & 0.53 & Tinggi \\
12 & Pemantauan Kendiri & 3.32 & 0.45 & Sederhana \\
13 & Berwawasan & 3.83 & 0.51 & Tinggi \\
14 & Transformasi & 4.11 & 0.49 & Tinggi \\
& Keseluruhan & 4.02 & 0.35 & Tinggi \\
\hline
\end{tabular}

Jadual 1: Profil Kepimpinan Pelajar Pintar dan Berbakat di Pusat PERMATA pintar Negara UKM

Jadual 1 menunjukkkan bahawa ciri kepimpinan PPB di Pusat PERMATA pintar Negara UKM yang paling tinggi ialah pemuafakatan $(\mathrm{min}=4.44$ dan $\mathrm{sp}=0.47)$, diikuti dengan tingkahlaku kepimpinan $(\min =4.29$ dan $\mathrm{sp}=0.54)$, kecekapan mempengaruhi $(\mathrm{min}=4.27$ dan $\mathrm{sp}=0.51)$, etika penghayatan kerohanian $(\min =4.23 \mathrm{dan} \mathrm{sp}=0.48)$, kemahiran hubungan kerja $(\mathrm{min}=4.17$ dan $\mathrm{sp}=0.48)$, transformasi $(\mathrm{min}=4.11 \mathrm{dan} \mathrm{sp}=0.49)$, kesepaduan $(\mathrm{min}=4.05$ dan $\mathrm{sp}=0.52)$, kepercayaan $(\min =4.00$ dan $\mathrm{sp}=0.57)$, kepintaran emosi $(\min =3.98$ dan $\mathrm{sp}=$ $0.53)$, motivasi memimpin $(\mathrm{min}=3.93$ dan $\mathrm{sp}=0.62)$, penghargaan kendiri $(\mathrm{min}=3.90$ dan $\mathrm{sp}=$ $0.59)$, efikasi kepimpinan $(\min =3.86$ dan $\mathrm{sp}=0.47)$ berwawasan $(\min =3.83$ dan $\mathrm{sp}=0.51)$, dan ciri kepimpinan yang sederhana (terendah) ialah pemantauan kendiri ( $\min =3.32$ dan $\mathrm{sp}=$ 0.45). Secara keseluruhannya dapatan menunjukkan bahawa kepimpinan pelajar pintar dan berbakat di Pusat PERMATA pintar Negara UKM berada pada tahap tinggi $(\mathrm{min}=4.02$ dan $\mathrm{sp}=$ 0.35). Bagi melihat kepimpinan pelajar pintar dan berbakat di Pusat PERMATA pintar Negara UKM dengan lebih jelas, maka perhatikan Graf 1 berikut:

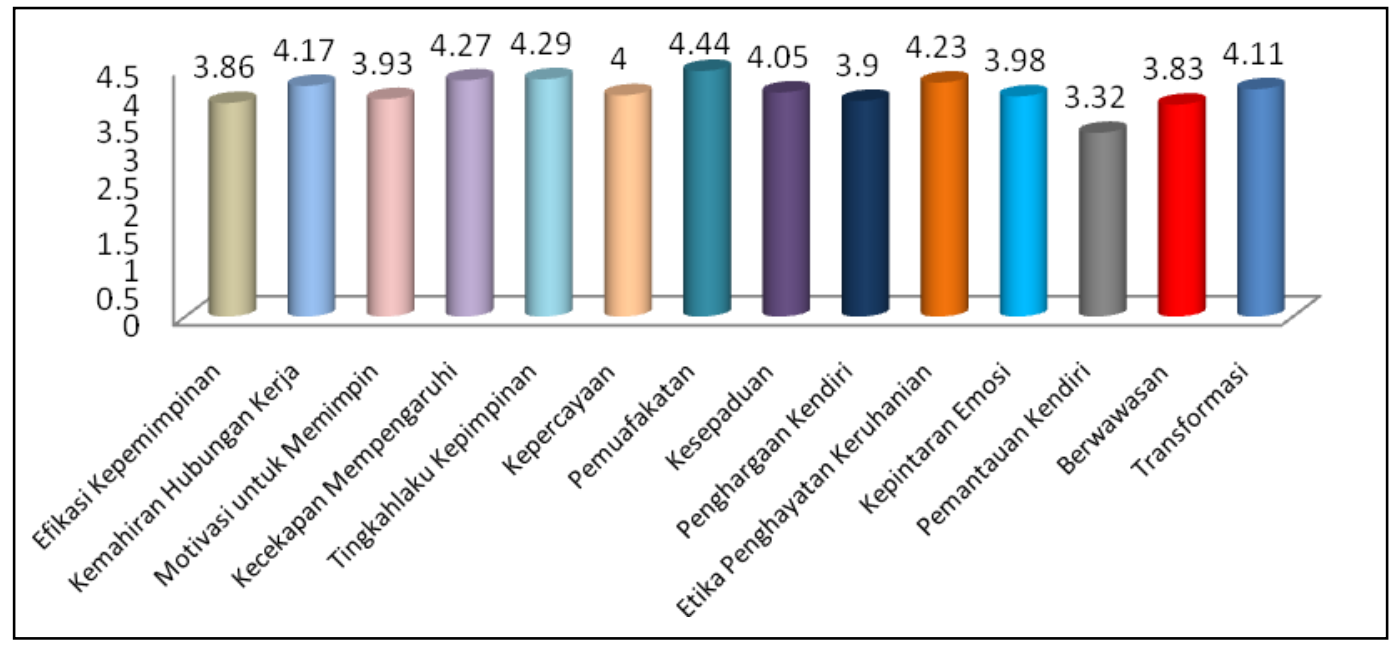

Graf 1: Kepimpinan Pelajar Pintar dan Berbakat di Pusat PERMATA Pintar Negara UKM

Graf tersebut menunjukkan bahawa pemuafakatan pelajar pintar dan berbakat di Pusat PERMATA pintar Negara UKM merupakan ciri kepimpinan yang paling tinggi. Manakala pemantauan kendiri merupakan ciri kepimpinan yang paling rendah. 


\section{Profil Kepimpinan PPB di Pusat PERMATA Pintar Negara UKM Mengikut Jantina, Kaum dan Program.}

Analisis deskriptif yang melibatkan min dan sisihan piawai dijalankan bagi menentukan profil kepimpinan PPB mengikut jantina, kaum, dan program di Pusat PERMATA pintar Negara Universiti Kebangsaan Malaysia. Hasil analisis deskriptif tersebut adalah sebagaimana pada Jadual 2 di bawah:

\begin{tabular}{|c|c|c|c|c|c|c|c|c|}
\hline \multirow{2}{*}{ Profil kepimpinan } & \multicolumn{2}{|c|}{ Jantina } & \multicolumn{4}{|c|}{ Kaum } & \multicolumn{2}{|c|}{ Program } \\
\hline & $\mathbf{L}$ & $\mathbf{P}$ & $\mathbf{M}$ & C & I & $\mathbf{L}$ & AP & PEND \\
\hline \multirow[t]{2}{*}{ Efikasi Kepimpinan } & 3.77 & 3.91 & 3.82 & 4.00 & 3.90 & 3.92 & 3.77 & 3.76 \\
\hline & .43 & .49 & .47 & .46 & .48 & .45 & .40 & .45 \\
\hline \multirow[t]{2}{*}{ Kemahiran Hubungan Kerja } & 4.13 & 4.20 & 4.12 & 4.34 & 4.10 & 4.42 & 4.14 & 4.20 \\
\hline & .49 & .47 & .46 & .36 & .82 & .51 & .42 & .52 \\
\hline \multirow[t]{2}{*}{ Motivasi untuk Memimpin } & 3.86 & 3.97 & 3.89 & 4.00 & 4.22 & 4.00 & 3.92 & 3.93 \\
\hline & .63 & .60 & .65 & .34 & .42 & .79 & .55 & .67 \\
\hline \multirow[t]{2}{*}{ Kecekapan Mempengaruhi } & 4.19 & 4.31 & 4.22 & 4.34 & 4.57 & 4.33 & 4.26 & 4.27 \\
\hline & .48 & .52 & .51 & .48 & .52 & .48 & .45 & .55 \\
\hline \multirow[t]{2}{*}{ Tingkahlaku Kepimpinan } & 4.25 & 4.31 & 4.28 & 4.38 & 4.12 & 4.33 & 4.35 & 4.24 \\
\hline & .52 & .55 & .57 & .41 & 54 & .48 & .49 & .58 \\
\hline \multirow[t]{2}{*}{ Kepercayaan } & 3.99 & 4.01 & 4.00 & 4.02 & 3.95 & 4.05 & 4.01 & 4.00 \\
\hline & .59 & .55 & .57 & .49 & .46 & .74 & .55 & .58 \\
\hline \multirow[t]{2}{*}{ Pemuafakatan } & 4.40 & 4.46 & 4.43 & 4.42 & 4.42 & 4.52 & 4.39 & 4.47 \\
\hline & .47 & .47 & .48 & .45 & .49 & .50 & .45 & .49 \\
\hline \multirow[t]{2}{*}{ Kesepaduan } & 4.07 & 4.04 & 4.08 & 3.97 & 3.67 & 4.12 & 3.97 & 4.12 \\
\hline & .53 & .52 & .53 & 53 & .21 & .51 & .47 & .56 \\
\hline \multirow[t]{2}{*}{ Penghargaan Kendiri } & 3.86 & 3.92 & 3.88 & 3.99 & 3.80 & 4.07 & 3.89 & 3.91 \\
\hline & .65 & .55 & .61 & .35 & .56 & .72 & .49 & .66 \\
\hline \multirow[t]{2}{*}{ Etika Penghayatan Keruhanian } & 4.17 & 4.26 & 4.20 & 4.34 & 4.05 & 4.33 & 4.23 & 4.23 \\
\hline & .53 & .45 & .47 & .43 & .47 & .68 & .44 & .51 \\
\hline \multirow[t]{2}{*}{ Kepintaran Emosi } & 3.92 & 4.01 & 3.95 & 4.02 & 3.87 & 4.27 & 3.94 & 4.01 \\
\hline & .50 & .55 & .54 & .38 & .67 & .50 & .53 & .53 \\
\hline \multirow[t]{2}{*}{ Pemantauan Kendiri } & 3.24 & 3.37 & 3.33 & 3.27 & 3.55 & 3.23 & 3.44 & 3.22 \\
\hline & .44 & .45 & .46 & .38 & .53 & .45 & .44 & .44 \\
\hline \multirow[t]{2}{*}{ Berwawasan } & 3.84 & 3.83 & 3.83 & 3.77 & 3.67 & 4.07 & 3.80 & 3.86 \\
\hline & .51 & .51 & .51 & .38 & .45 & .72 & .48 & .53 \\
\hline \multirow[t]{2}{*}{ Transformasi } & 4.20 & 4.06 & 4.08 & 4.26 & 3.97 & 4.20 & 4.11 & 4.11 \\
\hline & .45 & .51 & .49 & .49 & .53 & .43 & .50 & .48 \\
\hline
\end{tabular}

AP : Program ASASIpintar

PEND: Program Pendidikan

Jadual 2: Profil Kepimpinan Pelajar Pintar dan Berbakat di Pusat PERMATA Pintar Negara UKM

Jadual 2 menunjukkan taburan min dan sisihan piawai bagi aspek dalam kepimpinan (Efikasi Kepemimpinan, Kemahiran Hubungan Kerja, Motivasi untuk Memimpin, Kecekapan Mempengaruhi, Tingkahlaku Kepimpinan, Kepercayaan, Pemuafakatan, Kesepaduan, Penghargaan Kendiri, Etika Penghayatan Kerohanian, Kepintaran Emosi, Pemantauan Kendiri, Berwawasan dan Transformasi) pelajar pintar dan berbakat di Pusat PERMATA pintar Negara Universiti Kebangsaan Malaysia mengikut jantina, kaum dan kumpulan. Jadual 2 menunjukkan min efikasi kepimpinan pelajar perempuan $(\min =3.91, \mathrm{sp}=.49)$ lebih tinggi dari pelajar lelaki $(\min =3.77, \mathrm{Sp}=.43)$. Sementara pelajar Cina $(\mathrm{min}=4.00, \mathrm{sp}=.46)$ mencatat min lebih tinggi dari pelajar lain-lain kaum $(\mathrm{min}=3.92$ dan $\mathrm{sp}=.45)$, pelajar kaum India $(\mathrm{min}=3.90$ dan $\mathrm{sp}=$ $.48)$, dan pelajar kaum Melayu $(\min =3.82$ dan $\mathrm{sp}=.47)$. Pelajar program Asasi Pintar $(\mathrm{min}=$ 
3.77, $\mathrm{sp}=.40$ ) mencatat min efikasi kepimpinan yang lebih tinggi dari pelajar program Pendidikan Menengah ( $\min =3.76, \mathrm{sp}=.45)$.

Min kemahiran hubungan kerja pelajar perempuan $(\min =4.20, \mathrm{sp}=.47)$ lebih tinggi dari pelajar lelaki $(\min =4.13, \mathrm{Sp}=.49)$. Sementara pelajar lain-lain kaum $(\min =4.42, \mathrm{sp}=.51)$ mencatat min lebih tinggi dari pelajar kaum Cina ( $\min =4.34$ dan $\mathrm{sp}=.36$ ), pelajar kaum Melayu $(\mathrm{min}=4.12$ dan $\mathrm{sp}=.46)$ dan pelajar kaum India $(\min =4.10$ dan $\mathrm{sp}=.82)$. Pelajar program Pendidikan Menengah $(\mathrm{min}=4.20, \mathrm{sp}=.52)$ mencatat min kemahiran hubungan kerja yang lebih tinggi dari pelajar Asasi Pintar $(\min =4.14, \mathrm{sp}=.42)$. Seterusnya min motivasi untuk memimpin pelajar perempuan $(\mathrm{min}=3.97, \mathrm{sp}=.60$ ) lebih tinggi dari pelajar lelaki $(\mathrm{min}=3.86$, $\mathrm{Sp}=.63)$. Sementara pelajar kaum India $(\mathrm{min}=4.22$, $\mathrm{sp}=.42)$ mencatat min lebih tinggi dari pelajar kaum Cina ( $\min =4.00$ dan $\mathrm{sp}=.34)$, pelajar lain-lain kaum $(\min =4.00$ dan $\mathrm{sp}=.79)$ dan pelajar kaum Melayu $(\min =3.89$ dan $\mathrm{sp}=.65)$. Pelajar Asasi Pintar $(\min =3.92$, $\mathrm{sp}=.67$ ) mencatat min motivasi untuk memimpin yang lebih tinggi dari pelajar program Pendidikan Menengah $(\min =3.93, \mathrm{sp}=.55)$.

Min kecekapan mempengaruhi pelajar perempuan $(\mathrm{min}=4.31, \mathrm{sp}=.52)$ lebih tinggi dari pelajar lelaki $(\min =4.19, \mathrm{Sp}=.48)$. Sementara pelajar kaum India $(\min =4.57, \mathrm{sp}=.52)$ mencatat min lebih tinggi dari pelajar kaum Cina $(\min =4.34$ dan $\mathrm{sp}=.48$ ), pelajar lain-lain kaum $(\min =4.33$ dan $\mathrm{sp}=.48)$ dan pelajar kaum Melayu $(\min =4.22$ dan $\mathrm{sp}=.51)$. Pelajar program Pendidikan Menengah ( $\mathrm{min}=4.27, \mathrm{sp}=.55$ ) mencatat min kecekapan mempengaruhi yang lebih tinggi dari pelajar Asasi Pintar $(\min =4.26, \mathrm{sp}=.45$ ). Seterusnya min tingkahlaku kepimpinan pelajar perempuan $(\mathrm{min}=4.31, \mathrm{sp}=.55)$ lebih tinggi dari pelajar lelaki $(\mathrm{min}=4.25$, $\mathrm{sp}=.52)$. Sementara pelajar kaum Cina $(\mathrm{min}=4.38, \mathrm{sp}=.41)$ mencatat min lebih tinggi dari pelajar lain-lain kaum ( $\min =4.33$ dan $\mathrm{sp}=.48)$, pelajar kaum Melayu $(\min =4.28$ dan $\mathrm{sp}=.57$ ) dan pelajar kaum India (min $=4.12$ dan $\mathrm{sp}=.54)$. Pelajar Asasi Pintar $(\min =4.35, \mathrm{sp}=.49)$ mencatat min tingkahlaku kepimpinan yang lebih tinggi dari pelajar program Pendidikan Menengah $(\min =4.24, \mathrm{sp}=.58)$.

Min kepercayaan pelajar perempuan $(\min =4.01, \mathrm{sp}=.55$ ) lebih tinggi dari pelajar lelaki $(\mathrm{min}=3.99, \mathrm{sp}=.59)$. Sementara pelajar lain-lain kaum $(\mathrm{min}=4.05, \mathrm{sp}=.74)$ mencatat min lebih tinggi dari pelajar kaum Cina ( $\min =4.02$ dan $\mathrm{sp}=.49$ ), pelajar kaum Melayu $(\mathrm{min}=4.00$ dan $\mathrm{sp}$ $=.57)$ dan pelajar kaum India $(\min =3.95$ dan $\mathrm{sp}=.46)$. Pelajar Asasi Pintar $(\min =4.01, \mathrm{sp}=$ .55) mencatat min kepercayaan yang lebih tinggi dari pelajar program Pendidikan Menengah $(\mathrm{min}=4.00, \mathrm{sp}=.58)$. Seterusnya min pemuafakatan pelajar perempuan $(\min =4.46, \mathrm{sp}=.47)$ lebih tinggi dari pelajar lelaki $(\mathrm{min}=4.40, \mathrm{Sp}=.47)$. Sementara pelajar lain-lain kaum (min $=$ 4.52 , $\mathrm{sp}=.50)$ mencatat min lebih tinggi dari pelajar kaum Melayu ( $\min =4.43$ dan $\mathrm{sp}=.48)$, pelajar kaum Cina $(\mathrm{min}=4.42$ dan $\mathrm{sp}=.45)$ dan pelajar kaum India $(\min =4.42$ dan $\mathrm{sp}=.49$ ). Pelajar program Pendidikan Menengah $(\mathrm{min}=4.47, \mathrm{sp}=.49)$ mencatat min pemuafakatan yang lebih tinggi dari pelajar Asasi Pintar ( $\min =4.39$, $\mathrm{sp}=.45)$.

Min kesepaduan pelajar lelaki ( $\min =4.07, \mathrm{sp}=.53$ ) lebih tinggi dari pelajar perempuan $(\mathrm{min}=4.04, \mathrm{sp}=.52)$. Sementara pelajar lain-lain kaum $(\mathrm{min}=4.12, \mathrm{sp}=.51)$ mencatat min lebih tinggi dari pelajar kaum Melayu ( $\min =4.08$ dan $\mathrm{sp}=.53)$, pelajar kaum Cina $(\min =3.97$ dan $\mathrm{sp}$ $=.53$ ) dan pelajar kaum India $(\mathrm{min}=3.67$ dan $\mathrm{sp}=.21$ ). Pelajar program Pendidikan Menengah $(\mathrm{min}=4.12, \mathrm{sp}=.56)$ mencatat min kesepaduan yang lebih tinggi dari pelajar Asasi Pintar (min $=3.97, \mathrm{sp}=.47)$. Seterusnya min penghargaan kendiri pelajar perempuan $(\min =3.92, \mathrm{sp}=.55)$ lebih tinggi dari pelajar lelaki $(\mathrm{min}=3.86, \mathrm{sp}=.65)$. Sementara pelajar lain-lain kaum $(\mathrm{min}=$ 4.07, $\mathrm{sp}=.72$ ) mencatat min lebih tinggi dari pelajar kaum Cina ( $\min =3.99$ dan $\mathrm{sp}=.35$ ), pelajar kaum Melayu ( $\min =3.88$ dan $\mathrm{sp}=.61)$ dan pelajar kaum India $(\min =3.80$ dan $\mathrm{sp}=.56)$. Pelajar program Pendidikan Menengah ( $\min =3.91, \mathrm{sp}=.66)$ mencatat min penghargaan kendiri yang lebih tinggi dari pelajar Asasi Pintar ( $\min =3.89$, sp $=.49$ ).

Min etika penghayatan nilai kerohanian pelajar perempuan $(\min =4.26, \mathrm{sp}=.45)$ lebih tinggi dari pelajar lelaki $(\min =4.17, \mathrm{sp}=.53)$. Sementara pelajar kaum Cina $(\min =4.34$, $\mathrm{sp}$ $=.43$ ) mencatat min lebih tinggi dari pelajar lain-lain kaum ( $\min =4.33$ dan $\mathrm{sp}=.68$ ), pelajar 
kaum Melayu ( $\min =4.20$ dan $\mathrm{sp}=.47)$ dan pelajar kaum India $(\min =4.05$ dan $\mathrm{sp}=.47)$. Pelajar Asasi Pintar $(\mathrm{min}=4.23, \mathrm{sp}=.44)$ mencatat min etika penghayatan keruhanian yang sama dengan pelajar program Pendidikan Menengah $(\min =4.23, \mathrm{sp}=.51)$. Seterusnya $\min$ kepintaran emosi pelajar perempuan $(\mathrm{min}=4.01, \mathrm{sp}=.55)$ lebih tinggi dari pelajar lelaki $(\mathrm{min}=$ 3.92 , $\mathrm{sp}=.50)$. Sementara pelajar lain-lain kaum $(\min =4.27, \mathrm{sp}=.50)$ mencatat min lebih tinggi dari pelajar kaum Cina $(\mathrm{min}=4.02$ dan $\mathrm{sp}=.38)$, pelajar kaum Melayu $(\min =3.95$ dan $\mathrm{sp}=.54)$ dan pelajar kaum India $(\mathrm{min}=3.87$ dan $\mathrm{sp}=.67)$. Pelajar program Pendidikan Menengah $(\mathrm{min}=$ $4.01, \mathrm{sp}=.53$ ) mencatat min kepintaran emosi yang lebih tinggi dari pelajar Asasi Pintar (min = $3.94, \mathrm{sp}=.53)$.

Min pemantauan kendiri pelajar perempuan $(\min =3.37, \mathrm{sp}=.45)$ lebih tinggi dari pelajar lelaki $(\mathrm{min}=3.24$, sp $=.44)$. Sementara pelajar kaum India $(\min =3.55, \mathrm{sp}=.53$ ) mencatat min lebih tinggi dari pelajar kaum Melayu $(\min =3.33$ dan $\mathrm{sp}=.46)$, pelajar kaum Cina $(\min =3.27$ dan $\mathrm{sp}=.38)$ dan pelajar lain-lain kaum $(\min =3.23$ dan $\mathrm{sp}=.45)$. Pelajar Asasi Pintar ( $\min =3.44, \mathrm{sp}=44$ ) mencatat min pemantauan kendiri yang lebih tinggi dari pelajar program Pendidikan Menengah $(\mathrm{min}=3.22$, $\mathrm{sp}=.44)$. Seterusnya, min berwawasan pelajar lelaki $(\min =3.84, \mathrm{sp}=.51)$ lebih tinggi dari pelajar perempuan $(\min =3.83, \mathrm{sp}=.51)$. Sementara pelajar lain-lain kaum ( $\min =4.07, \mathrm{sp}=.72$ ) mencatat min lebih tinggi dari pelajar kaum Melayu ( $\min =3.83$ dan $\mathrm{sp}=.51)$, pelajar kaum Cina $(\min =3.77$ dan $\mathrm{sp}=.38)$ dan pelajar kaum India $(\mathrm{min}=3.67$ dan $\mathrm{sp}=.45)$. Pelajar program Pendidikan Menengah $(\mathrm{min}=3.86, \mathrm{sp}=$ .53) mencatat min berwawasan yang lebih tinggi dari pelajar Asasi Pintar ( $\min =3.80, \mathrm{sp}=.48$ ).

Min transformasi pelajar lelaki $(\mathrm{min}=4.20, \mathrm{sp}=.45$ ) lebih tinggi dari pelajar perempuan $(\min =4.06, \mathrm{sp}=.51)$. Sementara pelajar kaum Cina $(\min =4.26, \mathrm{sp}=.49)$ mencatat min lebih tinggi dari pelajar lain-lain kaum $(\mathrm{min}=4.20$ dan $\mathrm{sp}=.43)$, pelajar kaum Melayu $(\mathrm{min}=4.08$ dan $\mathrm{sp}=.49)$ dan pelajar kaum India $(\min =3.97$ dan $\mathrm{sp}=.53)$. Pelajar Asasi Pintar $(\min =4.11$, $\mathrm{sp}=.50$ ) mencatat min transformasi yang sama dengan pelajar program Pendidikan Menengah $(\min =4.11, \mathrm{sp}=.48)$.

\section{Perbincangan}

Secara keseluruhan dapatan kajian menunjukkan pelajar pintar dan berbakat (PPB) di Pusat PERMATA pintar Negara Universiti Kebangsaan Malaysia mempunyai tahap kepimpinan yang tinggi. Daripada empat belas ciri yang dikaji, tiga belas daripadanya memperoleh skor min yang tinggi dan sederhana tinggi (3.8 hingga 4.44) dan hanya satu ciri yang memperoleh skor min sederhana. Dapatan ini sejajar dengan pandangan Addison (1985) yang menyatakan kepimpinan adalah bidang potensi yang telah ditentukan dalam mendefinisi pelajar pintar dan berbakat. PPB didapati menonjol pada ciri pemuafakatan, tingkah laku kepimpinan, kecekapan mempengaruhi, etika penghayatan kerohanian, kemahiran hubungan kerja, transformasional, dan kesepaduan. Ciri-ciri ini merupakan kekuatan ciri kepimpinan yang tertanam dalam diri PPB. Penentuan potensi ini dapat membantu PPB menyedari akan kepentingan peranan kepimpinan mereka dalam bidang yang bakal dipilih. Keupayaan menyedari potensi diri boleh menyubur dan membangunkan bakat kepimpinan yang kemudiannya mampu mempengaruhi individu atau kumpulan lain untuk mencapai matlamat yang ditentukan. Pendapat ini menyokong pandangan (Roberts 2013) yang menyatakan kepimpinan adalah suatu kemestian bagi PPB kerana mereka menjadi role model kepada pelajar lain dalam persekitarannya.

Namun, apabila dilihat pada aspek ciri kepimpinan mengikut bangsa, dapatan menunjukkan pelajar berbangsa Cina, Panjabi, dan Bumiputera Borneo memperoleh skor yang lebih tinggi pada kebanyakan ciri kepimpinan yang dikaji, berbanding pelajar bangsa Melayu. Meskipun perbezaan skor adalah kecil, namun pelajar berbangsa Melayu yang rata-ratanya beragama Islam didapati kurang menonjol pada kebanyakan ciri-ciri kepimpinan berbanding kaum-kaum lain. Misalnya pada ciri sifat motivasi untuk memimpin dan kecekapan mempengaruhi, pelajar Melayu menduduki tempat keempat atau terakhir berbanding bangsa- 
bangsa yang lain. Bagi ciri-ciri kepimpinan yang lain seperti efikasi kepimpinan, hubungan kerja, tingkah laku kepimpinan, kepercayaan, pemuafakatan, etika penghayatan nilai kerohanian, kesepaduan, penghargaan kendiri, kepintaran emosi, berwawasan dan sifat transformasi, pelajar melayu berada pada tahap kedua atau ketiga. Keadaan ini memberi gambaran bahawa penghayatan nilai-nilai kepimpinan dalam kalangan PPB Melayu masih belum terserlah. Malah kecenderungan untuk memimpin dan kecekapan mempengaruhi masih berada di tahap yang rendah. Justeru, mereka perlu diberikan kesedaran tentang kepentingan membina kepimpinan diri dan didedahkan kepada peluang-peluang untuk mengasah bakat kepimpinan bagi mencapai kecemerlangan. Saranan ini sejajar dengan pandangan Gagne (2009) yang menyatakan sekiranya bakat ini tidak dicungkil dan dipupuk dengan baik, individu yang mungkin dilahirkan pintar, tidak akan berkembang untuk menjadikan dia seorang yang berbakat sepenuhnya.

Implikasi dapatan ini terhadap pembinaan kualiti kepimpinan remaja Islam amat besar, khususnya dalam aspek pembangunan sahsiah kepimpinan remaja Islam. Golongan remaja merupakan generasi yang bakal mewarisi peranan penting dalam persada kepimpinan negara di masa hadapan. Jatuh bangunnya tamadun dan pembangunan sesebuah negara khususnya Malaysia terletak di bahu generasi muda. Justeru, PPB khususnya pelajar Melayu perlu disedarkan tentang kepentingan membina kualiti kepimpinan bagi mengisi keperluan pemimpin negara masa depan. Malah, pemerkasaan ciri kepimpinan dalam kalangan pelajar Melayu perlu dijana kerana ia merupakan suatu tuntutan dalam agama Islam, iaitu setiap manusia yang lahir di muka bumi ini berperanan sebagai khalifah atau penguasa dan pemimpin di muka bumi sebagaimana kefahaman dari surah al-Baqarah (2:30). Apatah lagi PPB ini secara jelasnya telah dikurniai dengan potensi kecerdasan pemikiran (IQ) yang tinggi, yang membolehkan mereka mampu berfikir secara kritikal dan mendalami isu-isu kompleks secara mendalam (Chan 2003; Karnes \& Bean 1990). Keupayaan tersebut melangkaui batasan pemikiran pelajar atau remaja biasa yang 'ber-IQ' sederhana. Kecekapan pemikiran ini merupakan kualiti utama dalam diri seseorang pemimpin. Justeru mereka perlu disedarkan bahawa kurniaan IQ yang tinggi merupakan anugerah yang perlu digilap dan diperkasa menerusi penglibatan dalam pelbagai aktiviti sosial dan kemasyarakatan.

Sehubungan itu, pembinaan sahsiah kepimpinan yang holistik atau menyeluruh perlu disuburkan dan dihayati dengan penuh rasa tanggungjawab supaya kualiti kepemimpinan ini terjelma di segenap medan atau aktiviti yang diceburi. Usaha pembinaan kepimpinan yang berterusan ini bertujuan untuk mengangkat martabat kewibawaan remaja Islam dalam kalangan PPB, yang merupakan aset negara yang berkualiti bagi mengisi tampuk kepimpinan negara di masa hadapan. Akauntabiliti kepemimpinan ini diperingatkan oleh Allah s.w.t dalam surah al-An`am (6:165) yang bermaksud: "Dan Dialah yang menjadikan kamu penguasapenguasa/pemimpin-pemimpin di bumi dan Dia meninggikan kamu atas sebahagian yang lain beberapa darjat, untuk mengujimu tentang apa yang diberikan-Nya kepadamu. Sesungguhnya Tuhanmu amat cepat siksaan-Nya, dan sesungguhnya Dia Maha Pengampun lagi Maha Penyayang". Penegasan tentang kepentingan membina kualiti kepimpinan remaja Islam khususnya PPB ini sejajar dengan pemahaman pada surah al-Baqarah (2:124) yang menggambarkan betapa Islam amat mementingkan kualiti atau karakter peribadi individu yang layak menjadi pemimpin.

Maka, usaha memupuk ciri-ciri kepimpinan ini perlu bermula dari peringkat awal pendidikan. Dalam konteks pendidikan di sekolah, ciri ini perlu diterap dan disebatikan dalam kurikulum persekolahan agar proses pembinaan daya intelektual dan pembangunan sahsiah kepimpinan PPB dapat berjalan serentak. Pihak pengurusan pendidikan PPB menerusi Unit Bimbingan dan Kaunseling khususnya perlu komited dalam menyediakan program-program intervensi bagi menyedarkan pelajar khusus pelajar Melayu tentang tanggungjawab dan akauntabiliti kepemimpinan. Program tersebut perlu bermula dari peringkat awal kemasukan ke program pendidikan dan berterusan di sepanjang proses pendidikan berlangsung. Ini sejajar 
dengan pandangan Karnes dan Bean (1996) yang menyatakan, proses membina kualiti kepimpinan perlu dilalui secara berterusan menerusi pelbagai pendedahan dan pengalaman kokurikulum pada setiap peringkat perkembangan.

Selain itu, jawatankuasa akademik juga perlu memainkan peranan dengan mengintegrasikan komponen kepimpinan dalam subjek-subjek pengintegrasian ciri dan kemahiran kepimpinan pada setiap mata pelajaran dan aktiviti kokurikulum menerusi pendekatan kepimpinan merentas kurikulum (leadership across curriculum). Ia perlu dilaksanakan secara komited dalam program pendidikan PPB. Proses menjana pengalaman membina jatidiri kepimpinan ini juga perlu menyeimbangkan penglibatan pelajar lelaki dan perempuan serta komposisi pelbagai kaum. Ini bagi membolehkan PPB mempelajari dan mencontohi karakter dan kemahiran kepemimpinan rakan-rakan pelbagai latar belakang menerusi pemerhatian sepanjang penglibatan dalam aktiviti yang dilalui. Kepentingan mencontohi kejayaan orang lain menerusi pemerhatian yang dikenali sebagai vicarious learning (Bandura 1994) ternyata dapat memberi kesan yang mendalam sepanjang usaha membentuk efikasi kendiri (kepercayaan/ keyakinan kendiri) yang merupakan salah satu ciri dalam karakter pemimpin. Malah peranan kepimpinan pelajar kaum Melayu dan pelajar lelaki perlu diserlahkan. Ini berikutan dapatan yang menunjukkan pelajar kaum Melayu masih berada di tahap sederhana dan pelajar perempuan pula mengatasi pelajar lelaki dalam hampir kesemua ciri kepimpinan.

Untuk itu, pihak pengurusan perlu menyediakan peluang yang luas dalam usaha membina ciri karismatik kepimpinan PPB. Usaha tersebut boleh dilakukan menerusi galakan terhadap pelbagai aktiviti kokurikulum bermula dari peringkat dalaman (sekolah, daerah, kebangsaan) sehinggalah ke peringkat antarabangsa. Persekitaran pembelajaran yang luwes dan pendedahan pengalaman yang luas, seperti penglibatan dalam program-program khidmat masyarakat di peringkat nasional dan global akan dapat memacu kecemerlangan PPB dalam menjana kualiti kepemimpinan, sepertimana yang disebut oleh Duke (2011) usaha membina ciri kepimpinan bukan terletak pada jawatan dan kedudukan sebagai ketua atau pemimpin, sebaliknya proses pengalaman yang melibatkan diri dalam merangka dan melaksanakan perancangan, merupakan kunci utama yang dapat mengembangkan potensi kepemimpinan pelajar.

Secara keseluruhan, hasil dapatan kajian ini menunjukkan bahawa PPB mempunyai kekuatan dan kekurangan pada aspek-aspek kepimpinan yang dikaji. Kekuatan yang dimiliki perlu diiktiraf dan diperkasa manakala kekurangannya pula perlu diperbaiki dan dipertingkatkan. Usaha pembinaan dan penambahbaikan perlu dilaksanakan secara terancang menerusi program-program pendidikan pintar dan berbakat. Semua program pendidikan di setiap peringkat persekolahan, khususnya program pembangunan karakter atau jatidiri pelajar perlu memfokuskan perancangan aktiviti ke arah membina karakter pemimpin. Aktiviti yang dirancang harus dapat mencungkil bakat kepimpinan, memberi peluang menjana pengalaman memikul tanggungjawab kepemimpinan secara individu atau berkumpulan, dan diperluaskan penglibatan kepimpinan di pelbagai peringkat, sama ada di peringkat sekolah, daerah, negeri, kebangsaan dan antarabangsa. Satu Model Program Kepimpinan Bersepadu perlu dibentuk bagi memenuhi keperluan pembangunan kepemimpinan PPB. Model Program Kepimpinan Bersepadu ini perlu mencakupi komponen pengetahuan kepimpinan, kemahiran dan kecekapan kepemimpinan, serta komponen pembangunan sikap dan nilai kepimpinan. Pelaksanaan program perlu melibatkan pengaplikasian teori ke dalam praktikal, supaya pelajar dapat menggembleng pengetahuan dan kemahiran yang dipelajari menerusi pengalaman sebenar memimpin sesuatu aktiviti atau program yang dirancang. Malah mereka juga perlu diberi pendedahan untuk bekerja bersama tokoh pemimpin mengikut bidang kepimpinan yang dipilih (Leaders Mentorship Programme). Selain itu, konsep 'Satu Pelajar Satu Tokoh" perlu diketengahkan sebagai usaha membina jatidiri kepimpinan kendiri dalam kalangan PPB. Hal ini 
bagi membantu mereka menjana keyakinan dan memupuk semangat kepemimpinan sebagai bakal pemimpin cemerlang di masa hadapan.

\section{References}

Al-Quran.

Addisson, L. 1985. Leadership skills among the gifted and talented. Ericdigests.org. Reston: ERIC Clearinghouse on Handicapped and Gifted Children.

Aliza Alias \& Hamidah Yamat. 2009. Ciri-ciri kanak-kanak pintar cerdas. PERMATApintar Negara: Pengalaman UKM. Bangi: Pusat PERMATApintar Negara.

Bandura, A. 1994. Self-efficacy. Dlm. V.S. Ramachaundran (pnyt.). Encyclopedia of Human Behavior, hlm. 71-81. Jil. 4. New York: New York Academic Press.

Bisland, A. 2004. Developing leadership skills in young gifted students. Gifted Child Today 27(1): 24-27. http://eric.ed.gov/?id=EJ682651. [15 March 2014].

Brown, M., Trevino, L. \& Harrison, D. 2005. Ethical leadership: A social learning perspective for construct development and testing. The Leadership Quarterly 97: 125.

Burke, C.S., Stagl, K.C., Klein, C., Goodwin, G.F., Salas, E., \& Halpin, S.M. 2006. What type of leadership behaviours are functional in teams? A Meta-Analysis. The Leadership Quarterly. 17: 72-119.

Chan, D.W. 2003. Assessing leadership among Chinese secondary students in Hong Kong: The use of the Roets rating scale for leadership. Gifted Child Quarterly 44(2): 115-122.

Chan, K.Y. \& Drasgow, F. 2001. Toward a theory of individual differences and leadership: Understanding the motivation to lead. Journal of Applied Psychology 86(3): 481-498.

Dobbins, G.H., Long, W.S., Dedrick, E.J. \& Clemons, T.C. 1999. The role of self-monitoring and gender on leader emergence: A laboratory and field study. Journal of Management 16(3): 609-618.

Duke Letter. 2011. Defining Giftedness and Its Goals. Digest of Gifted Research. t.tp.: Duke Talent Identification Program.

Feldhusen, J.F. \& Bleiss, M.K. 1994. Leadership: A synthesis of social skills, creativity, and histrionic ability? Roeper Review 16: 292-293.

Gagne, F. 2009. Building gifts into talents: Brief overview of the DMGT 2.0. http://www.giftedconference2009.org/presenter_files/gagne_p12_therealnature.pdf. [15 March 2014]

Goleman, D., Boyatzis, R., \& McKee, A. 2014. Primal leadership. http://changingminds.org/disciplines/leadership/styles/six_emotional_styles.htm. [15 March 2014].

Heerman, B. 1995. Spiritual core is essential to high performing teams. The New Leaders 2: 4-5.

Karnes, F.A. \& Bean, S.M. 1996. Leadership development and the gifted. Focus on Exceptional Children 29(1): 1-12.

Karnes, F.A. \& Stephens, K.R. 1999. Lead the way to leadership education. Education Digest 64(8): 62-65.

Landau, E. \& Weissler, K. 1991. Tracing leadership in gifted children. Journal of Psychology 125: 681-688.

Locke, E.A., Kirkpatrick, S., Wheeler, J.K., Schneider, J., Niles, K., Goldstein, H., Welsh, K. \& Chah, D.0. 1991. The Essence of Leadership. The Four Keys to Leading Successfully. New York: Lexington Books.

Mahmud Yunus. 2010. Tafsir Mahmud Yunus: Al-Quran nul Karim Rasm Uthmani. Kuala Lumpur: Penerbit KBC.

Mansfield, S. 2014. Teachers as transformers - within the differentiated model of giftedness and talent gifted. http://www.gifted.tki.org.nz/content/download/1466/8866/file/ Teachers\%2520as\%2520Transformers. [9 February 2014]. 
Matsumoto, D., Weissman, M.D., Preston, K., Brown, B.R. \& Kupperbausch, C. 1997. Contextspecific measurement of individualism-collectivism on the individual level: The Individualism-Collectivism Interpersonal Assessment Inventory. Journal of CrossCultural Psychology 28(6): 743-767.

McAllister, D.J. 1995. Affect and cognitive based trust as foundations for interpersonal cooperation in organizations. Academy of Management Journal 38: 24-59.

Meyer, J.P. \& Allen, N.J. 1997. Commitment in the Workplace: Theory, Research, and Application. Thousand Oaks, CA: Sage.

Pearce, C.L. 2004. The future of leadership: Combining vertical and shared leadership to transform knowledge work. Academy of Management Executive 18(1): 47-57.

Philips., C. E. 2009. An exploration of identification of leadership for gifted students. ProQuest Dissertations and Theses. http://www. udini.proq uest.com/view/an-exploration-ofidentification-of-pqid:1934839251. [6 December 2013].

Pierce, J. L., Gardner, D.G., Cummings, L.L. \& Dunham, R.R. 1998. Organization based self-esteem. construct definition, measurement, and validation. Academy of Management Journal 32: 622-648.

Pillai, R. \& Williams, E. 2004. Transformational leadership, self-efficacy, group cohesiveness, commitment, and performance. Journal of Organization Change Management. 17(2): 144-159.

Renzulli, J. S. 1978. What Makes Giftedness? Re-examining a Definition. Phi Delta Kappa 60: 180-181.

Roberts. J.L. 2013. leadership_is_a_must. http://www.wku.edu/gifted/documents/resource_ articles/leadership_is_a_must.pdf. [6 December 2013].

Rosadah Abd Majid, Noriah Mohd Ishak \& Melor Md Yunus. 2009. Kepintaran dan pintar cerdas berbakat: Definisi dan makna. PERMATApinta Negara: Pengalaman UKM. Bangi: Pusat PERMATApintar Negara.

Hannah, S.T., Avolio, B., Luthans, F. \& Harms, P.D. 2008. Leadership efficacy: Review and future directions. The Leadership Quarterly 1-25. http://digitalcommons.unl.edu/cgi/viewcontent.cgi?article=1005\&context=managemen tfacpub. [20 June 2013].

Sherer. M., Maddux, J.E., Mercandante, S., Dunn, S.P., Jacobs, B. \& Rogers, R.W. 1992. The selfefficacy scale: Construction and validation. Psychological Reports 53: 899-902.

Sisk. D. 2000. Understanding and encouraging leadership giftedness. Tempo 20(1): 19-23.

Staw, B.M. \& S.G. Basade. 1993. Affect and managerial performance: A test of the sadder-butwiser vs. the happier-and-smarter hypothesis. Administrative Science Quarterly 38(2): 304-331.

Sternberg, R.J. 2004. Definitions and Conceptions of Giftedness. Thousands Oaks, CA: Corwin Press.

Tapia, M. 2001. Measuring emotional intelligence. Psychological Reports 88: 353-364.

Terry, G.R. 2006. Principles of Management. Terj. Winardi. Bandung: Alumni.

The National Association for Gifted Children. 2010. http://www.nagc.org/resourcespublications/nagc-publications/gifted-child-quarterly. [11 March 2014].

Yukl, G. \& Falbe, C.E. 1990. Influence tactics and objectives ini upward, downward, and lateral influence attempts. Journal of Applied Psychology 75(2): 134. 